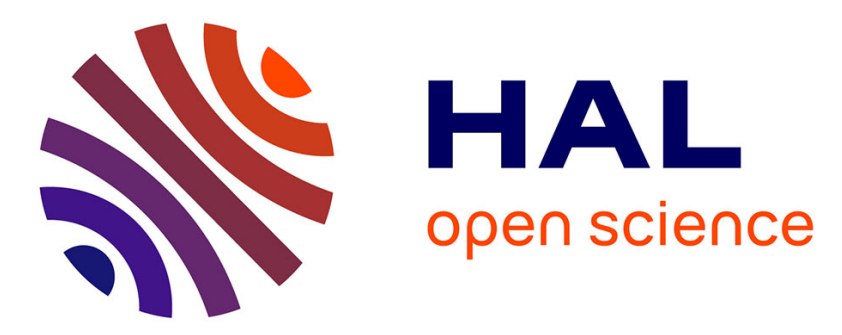

\title{
EXAFS AND XANES STUDIES ON THE LOCAL STRUCTURES OF METAL IONS IN METAL DOPED MgO SYSTEMS
}

K. Asakura, Y. Iwasawa, H. Kuroda

\section{- To cite this version:}

K. Asakura, Y. Iwasawa, H. Kuroda. EXAFS AND XANES STUDIES ON THE LOCAL STRUCTURES OF METAL IONS IN METAL DOPED MgO SYSTEMS. Journal de Physique Colloques, 1986, 47 (C8), pp.C8-317-C8-320. 10.1051/jphyscol:1986862 . jpa-00226184

\section{HAL Id: jpa-00226184 \\ https://hal.science/jpa-00226184}

Submitted on 1 Jan 1986

HAL is a multi-disciplinary open access archive for the deposit and dissemination of scientific research documents, whether they are published or not. The documents may come from teaching and research institutions in France or abroad, or from public or private research centers.
L'archive ouverte pluridisciplinaire HAL, est destinée au dépôt et à la diffusion de documents scientifiques de niveau recherche, publiés ou non, émanant des établissements d'enseignement et de recherche français ou étrangers, des laboratoires publics ou privés. 
EXAFS AND XANES STUDIES ON THE LOCAL STRUCTURES OF METAL IONS IN METAL DOPED MgO SYSTEMS

\author{
K. ASAKURA, Y. IWASAWA and H. KURODA \\ Department of Chemistry, Faculty of Science, the University of \\ Tokyo, Hongo, Bunkyo-ku, Tokyo 113, Japan
}

\title{
Abstract:
}

The local structures around the metals in metal-doped Mgo catalysts were studied by EXAFS and XANES spectroscopies in connection with their catalysis which markedly depends on the kinds of doped metal ions. In the $M-M g O$ samples $\left(M=\mathrm{Ni}^{2+}, \mathrm{Cu}^{2+}\right.$, and $\left.\mathrm{Co}^{2+}\right)$, the $\mathrm{M}$ ions occupied the octahedral sites of Mgo lattice by replacement with $\mathrm{Mg}^{2+}$. On the other hand, in the system of $M-M g O$ samples $\left(M=\mathrm{Fe}^{3+}\right.$ and $\left.\mathrm{Cr}^{3+}\right)$ the $M$ ions existed as the cluster structure with a Koch-Cohen type $\mathrm{M}_{4}$-framework. The pair sites of the cation vacancy and basic oxygen atom derived from the cluster formation may be corrected with the specific catalysis for the cross-coupling reaction.

\section{Introduction}

Magnesium oxide (MgO) is known as a representative basic catalyst. When $\mathrm{MgO}$ is doped with $\mathrm{Ni}^{2+}$ or $\mathrm{Cu}^{2+}$, the surface basicity increases 1 ). In contrast, Mgo doped with $\mathrm{Fe}^{3+}$ or $\mathrm{Cr}^{3+}$ ion is converted to be active catalyst for the cross-coupling reaction between methanol and acetonitrile or acetone to form unsaturated compouds 2 ). The local structures around the added metals play an important role for the catalytic feature of those modified Mgo samples. In the present paper EXAFS and XANES spectra of the metals added to the Mgo were measured and analyzed in order to find the correlation between the local structures of the doped metals and the catalytic properties.

\section{Experimental}

The metal-doped Mgo was prepared by the impregnation of Mgo (Soekawa Chemicals Co. 99.99 8) with the aqueous solutions of $\mathrm{Cr}^{3+}$, $\mathrm{Fe}^{3+}, \mathrm{Cu}^{2+}, \mathrm{Ni}{ }^{2+}$ and $\mathrm{Co}^{2+}$ nitrates, followed by the calcination at 873 $\mathrm{K}$ in a flow of $\mathrm{N}_{2}$. $\mathrm{Ni}^{2+}$ and $\mathrm{Co}^{2+}$ are known to form solid solutions with Mgo in the whole range of metal concentrations. The amounts of added metals were $5 \mathrm{wt} \%$. The $X$-ray diffraction patterns showed no separated metal oxide phase in all samples.

$\mathrm{X}$-ray absorption spectra were measured at $80 \mathrm{~K}$ using synchrotron radiation on an EXAFS spectrometer installed at $B L-10 B$ of photon Factory in National Laboratory for High Energy Physics (KEK-PF) 3). The EXAFS data were analyzed by a curve fitting techniques 4$)^{5}$ ). 


\section{Results and Discussion}

From the results of EXAFS and XANES, the samples were classified into two groups. The first group includes $\mathrm{Ni}^{2+}, \mathrm{CO}^{2+}$ and $\mathrm{Cu}^{2+}$-doped Mgo catalysts (Group 1) where the increase of basicity by the addition of the metal ions has been observed. The second group includes $\mathrm{Fe}^{3+}-$ and $\mathrm{Cr}^{3+}$-doped catalysts (Group 2 ) which have been found to show the high activities for the MgO system on the reaction. We describe EXAFS and XANES analyses of $\mathrm{Ni}^{2+}$ - and $\mathrm{Fe}^{3+}$-doped $\mathrm{MgO}$ samples as the typical examples in each group.

Figures 1 and 2 show the XANES spectra of $\mathrm{Ni}$ and $\mathrm{Fe} \mathrm{K}$-edges of the $\mathrm{Ni}^{2+}-\mathrm{MgO}$ and $\mathrm{Fe}^{3+}$-MgO catalysts, respectively. The weak absorption peak observed in the pre-edge region in Fig.1 is assigned to $1 \mathrm{~s}-3 \mathrm{~d}$ transition. It is demonstrated that the transition is weak in intensity when metal atoms are located in an octahedral position 6$)$. The pre-edge peak in the XANES spectrum of $\mathrm{Fe} \mathrm{K}$-edge in Fig. 2 was rather strong, suggesting that $\mathrm{Fe}^{3+}$ ions are located at tetrahedral sites without' symmetry-center ${ }^{6}$ ).

Figures 3 and 4 show the Fourier transforms extracted from the EXAFS data for $\mathrm{Ni}^{2+-d o p e d ~ a n d ~} \mathrm{Fe}^{3+}$-doped MgO catalysts, respectively. Since the back-scattering powers as well as phase shift functions of $\mathrm{Mg}^{2+}$ and of $\mathrm{Ni}^{2+}$ or $\mathrm{Fe}^{3+}$ differ, these elements are indistinguishable in the fitting process in $k$-space. Thus the first peak of the Fig. 3 was assigned to $\mathrm{Ni}-\mathrm{O}$ bond and the second one was due to Ni-Mg bond by the curve fitting analysis. No $\mathrm{Ni}-\mathrm{Ni}$ bond was observed. The distances of $\mathrm{Ni}-\mathrm{O}$ and $\mathrm{Ni}-\mathrm{Mg}$ are $2.09 \AA$ and $2.95 \AA$, respectively as shown in Table 1. The coordination numbers of $\mathrm{O}$ and $\mathrm{Mg}$ atoms around $\mathrm{a}$ $\mathrm{Ni}$ atom were 6 and 11 , respectively. These distances and coordination numbers are in good agreement with those expected when the $\mathrm{Ni}^{2+}$ ions occupy the $\mathrm{Mg}^{2+}$ sites in Mgo crystal as illustrated in Fig.5. The same conclusion was drawn with $\mathrm{Co}^{2+}-\mathrm{MgO}$ and $\mathrm{Cu}^{2+}-\mathrm{MgO}$ catalysts.

on the other hand, the $\mathrm{Fe}^{3+}$-doped MgO sample showed the different Fourier transform in Fig.4. The curve fitting analysis showed that the first peak is attributed to $\mathrm{Fe}-\mathrm{O}$ and the second one is made up by the superposition of $\mathrm{Fe}-\mathrm{Fe}$ and Fe-Mg bonds. The determined Fe-O distance $(1.90 \AA)$ corresponded to the sum of the ignic radii of $\mathrm{O}^{2}-(1.40 \AA)$ and tetrahedrally coordinated $\left.\mathrm{Fe}^{3}+(0.49 \AA) 7\right)$ and the coordination number of $O$ atoms around a $F e$ atom was nearly 4 . The EXAFS data also indicated that the $F e$ ions are situated in a tetrahedral position. The second remarkable point is the existence of Fe-Fe bonds at a distance of $2.99 \AA$, suggesting the cluster formation. The Fe-Mg distance is $3.31 \&$ which is much longer than that of $\mathrm{Ni}-\mathrm{Mg}$ bond distance. We propose the Koch-Cohen-type structure as a model structure for the $\mathrm{Fe}^{3+-M g O}$ system as depicted in Fig.6. The structure has been postulated to exist in a non-stoichiometrical Fe $\mathrm{F}^{\mathrm{O}} \mathrm{\text {sample }}$ obtained from Feo contains $\mathrm{Fe}^{3+}$ ions and cation vacancies ${ }^{8}$. In this structure $4 \mathrm{Fe}^{3+}$ ions and the 13 cation vacancies gather to form the cluster structrues, where $\mathrm{Fe}^{3+}$ ions are located in tetrahedral positions. In the $\mathrm{Fe}^{3+-} \mathrm{MgO}$ catalyst the $\mathrm{Fe}_{4}$ cluster structure may be dispersed in the Mgo crystal(lattice constant $: 4.20 \AA$ ) as shown in Fig.6. The bond distances $\mathrm{F} g \mathrm{Fe}-\mathrm{O}, \mathrm{Fe}-\mathrm{Fe}$, and $\mathrm{Fe}-\mathrm{Mg}$ expected from this model are $1.86 \AA, 2.98 \AA$ and $3.42 \AA$, respectively. These values are in good agreement with those obtained from the EXAFS analyses as shown in Table 1. The small coordination number for $\mathrm{Fe}-\mathrm{Fe}$ and $\mathrm{Fe}-\mathrm{Mg}$ bonds observed in the EXAFs results may be due to the distortion of the ideal $\mathrm{Fe}_{4}$-cluster structure. The formation of similar $\mathrm{Cr}_{4}-$ clusters were indicated for the $\mathrm{Cr}^{3+}-\mathrm{MgO}$ system on the basis of the EXAFS and XANES studies.

The high catalytic activities of the $\mathrm{Fe}^{3+-M g O}$ and $\mathrm{Cr}^{3+}-\mathrm{MgO}$ catalysts for the cross-coupling reaction may be related to the specific cluster formation. Acetone and acetonitrile adsorb at the cation vacancies and strongly interact with $\mathrm{Fe}^{3+}$ ions of the cluster. 


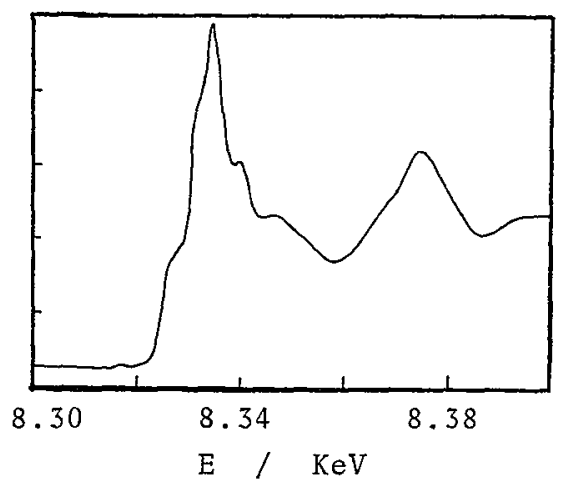

Fig. $1 \mathrm{Ni}$ K-edge XANES spectrum

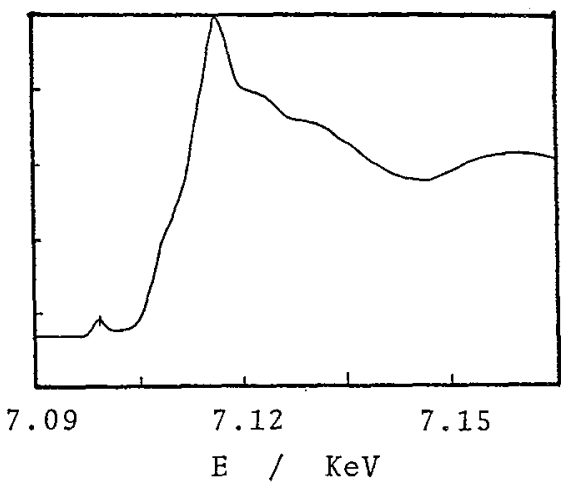

Fig.2 Fe K-edge XANES spectrum

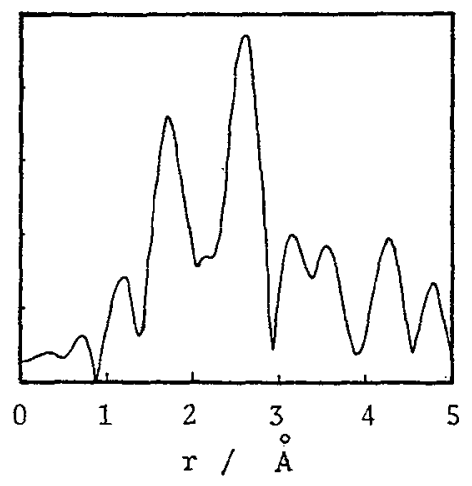

Fig. 3 Ni EXAFS Fourier transform

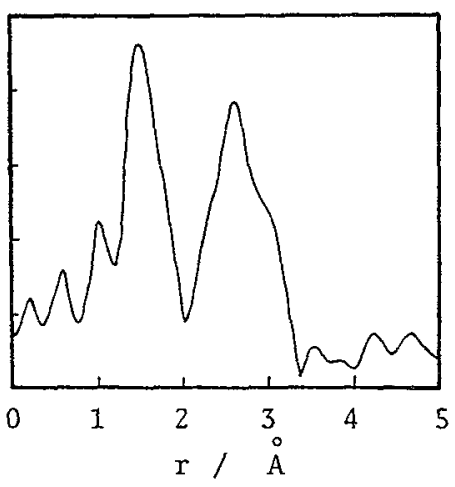

Fig. 4 Fe EXAFS Fourier transform

Table 1 Curve fitting results of M-MgO

\begin{tabular}{|c|c|c|c|c|c|c|}
\hline \multirow[t]{2}{*}{ M-MgO } & \multicolumn{2}{|r|}{$M-0$} & \multicolumn{2}{|r|}{$M-M$} & \multicolumn{2}{|r|}{$\mathrm{M}-\mathrm{Mg}$} \\
\hline & $\overline{C . N .}$ & $r / A$ & C.N. & $r / A$ & $\overline{C . N}$. & $\mathrm{I} / \mathrm{A}$ \\
\hline $\begin{array}{l}\mathrm{Co}-\mathrm{MgO} \\
\mathrm{Ni}-\mathrm{MgO} \\
\mathrm{Cu}-\mathrm{MgO}\end{array}$ & $\begin{array}{l}5(1) \\
6(1) \\
3(1)\end{array}$ & $\begin{array}{l}2.13(3) \\
2.09(3) \\
2.01(4)\end{array}$ & & & $\begin{array}{l}11(2) \\
11(2) \\
10(2)\end{array}$ & $\begin{array}{l}2.97(4) \\
2.95(4) \\
2.98(4)\end{array}$ \\
\hline $\begin{array}{l}\mathrm{Fe}-\mathrm{MgO} \\
\mathrm{Cr}-\mathrm{MgO}\end{array}$ & $\begin{array}{l}4(1) \\
3(1)\end{array}$ & $\begin{array}{l}1.90(3) \\
1.94(3)\end{array}$ & $\begin{array}{l}2(1) \\
2(1)\end{array}$ & $\begin{array}{l}2.99(4) \\
2.95(4)\end{array}$ & $\begin{array}{l}4(2) \\
3(2)\end{array}$ & $\begin{array}{l}3.31(4) \\
3.32(5)\end{array}$ \\
\hline
\end{tabular}


Through the lone pair electrons of the ketone or nitrile groups so that the rupture of $\mathrm{C}_{\alpha}-\mathrm{H}$ bond is promoted, while the ability of oxygen atoms located adjacently to the vacancies for hydrogen abstraction from methanol increases by the coordination unsaturation. Thus the pair sites of Lewis-acidic cation vacancy and basic oxygen atom produced from the clusterization of doped metal ions are likely to be the origin of the cross-coupling catalysis. The correlation between the increase of the surface base concentration and the structure of $\mathrm{M}-\mathrm{MgO}\left(\mathrm{M}=\mathrm{Ni}^{2+}, \mathrm{Cu}^{2+}, \mathrm{Co}^{2+}\right)$ systems is not clear, but this phenomenon must be related to the localization of d electrons of the transition metal embedded in the insulator Mgo-crystal.

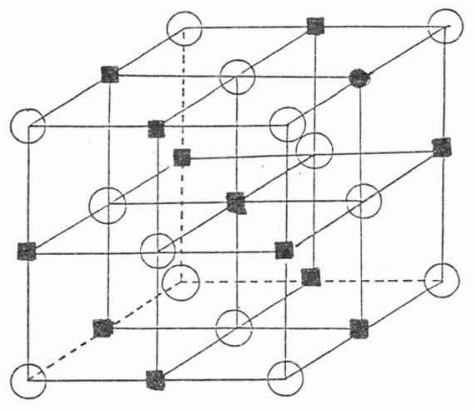

$\bigcirc \mathrm{O}^{2-}, \mathrm{Mg}^{2+}, \mathrm{Ni}^{2+}$

Fig. 5 A model for $\mathrm{Ni}^{2+}-\mathrm{MgO}$.

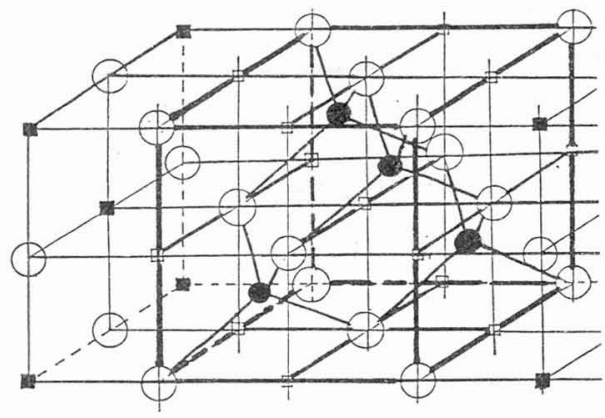

$\mathrm{OO}^{2-}, \mathrm{Mg}^{2+}, \square \mathrm{c} \cdot \mathrm{v} \cdot \mathrm{Fe}^{3+}$

c. v. = cation vacancy

Fig. 6 A model for $\mathrm{Fe}^{3+}-\mathrm{MgO}$.

References

1)W.Ueda, T.Yokoyama, Y.Moro-Oka, and T.Ikawa, Chem.Lett., 1985 , 1059.

2)W.Ueda, T.Yokoyama, Y.Moro-Oka, and T.Ikawa, J.Chem.Soc.,Chem. Commun. 1984, 391; Ind. Eng.Chem.Prod.,Res.Dev., 24, 340(1985); W.Ueda, H.Kurokawa, Y.Moro-oka, and T.Ikawa, Chem.Lett. $1985,39$.

3)H.Oyanagi, T.Matsushita, M.Ito, and H.Kuroda, KEK Report, (1984) $83-30$.

4)B.K.Teo, P.A.Lee, A.L.Simons, P.Eisenberger, and B.M.Kincaid, J.Am.Chem.Soc., 99, 3854(1977); P.A.Lee, B.K.Teo, and A.L.Simons, J.Am. Chem.Soc., 99, 3856(1977).

$5)$ The details of EXAFS analyses for the metal-doped Mgo catalysts will be given in the following paper.

6)F.W.Kutzler, SSRL Report, 80/01.(1980).

7)R.D.Shannon and C.T.Prewitt, Acta Cryst., B25, 925(1969).

8)F.Koch and J.B.Cohen, Acta Cryst.,B25, 275(1969). 